\title{
Konseling sebagai Sanksi Pidana Tambahan pada Tindak Pidana Kekerasan dalam Rumah Tangga
}

\author{
Aroma Elmina Martha, Ria Hayuna \\ Dosen Fakultas Hukum Universitas Islam Indonesia \\ Alumni Fakultas Hukum Universitas Islam Indonesia \\ Jl. Tamansiswa No. 158 Yogyakarta \\ snowy6869@yahoo.com
}

\begin{abstract}
This research discusses: first, the tendency of judges to impose imprisonment without considering any additional criminals in the form of counseling as a criminal sanction in KDRT (domestic violence); second, effective applicable policies in the implementation of Criminal Counseling. This research used normative approach with empirical data. The method of data collection was interview to judges to obtain primary data. The finding of this research shows: first, based on the existing facts, judges have never implemented any additional criminal in the form of counseling because it has not been well-known in court; there has not been any prosecution using Article 50 of UU PKDRT; the institution for counseling has not been established yet. Second, in the implementation of additional criminal counseling, efficient applicable policies in the future should refer to the idea of double track system, by optimizing both types of sanctions in a proportional manner (criminal sanctions and measures). Revision for stipulation in Article 50 point $b$ is needed, so that it is more understandable and can soon be implemented by judges. In addition, the arrangement of standard operating procedure is needed for the implementation, supervision, and report of counseling process for the subject of domestic violence.
\end{abstract}

Keywords : Additional criminal counseling, applicable policy

\begin{abstract}
Abstrak
Penelitian ini mengkaji permasalahan: pertama, kecenderungan hakim menjatuhkan pidana penjara tanpa mempertimbangkan pidana tambahan berupa konseling sebagai sanksi pidana dalam KDRT; Kedua, kebijakan aplikatif yang efektif dalam penerapan Pidana Tambahan Konseling. Pendekatan penelitian ini menggunakan pendekatan normatif, yang didukung data empiris, metode pengolahan dan penyajian data penelitian ini peneliti peroleh berupa data primer melalui wawancara kepada hakim. Hasil penelitian menunjukkan: pertama, berdasarkan fakta yang ada, hakim belum pernah menerapkan pidana tambahan berupa konseling dikarenakan pidana konseling belum banyak dikenal di lingkup peradilan dan belum adanya tuntutan jaksa yang menggunakan pasal 50 UU PKDRT serta belum diaturnya lembaga yang ditunjuk dalam pelaksanan konseling. Kedua, kebijakan aplikatif yang efektif ke depan dalam penerapan pidana tambahan konseling harus merujuk pada ide double track system, dengan memaksimalkan kedua jenis sanksi secara proposional (sanksi pidana dan tindakan. Perlu adanya penyempurnaan atau merevisi ketentuan Pasal 50 huruf b, sehingga lebih jelas dan dapat segera diimplementasikan oleh Hakim. Selain itu diperlukan penyusunan standar operasional prosedur untuk pelaksanaan dan pengawasan serta pelaporan proses konseling bagi pelaku KDRT.
\end{abstract}

Kata kunci : Pidana tambahan konseling, kebijakan aplikatif 


\section{Pendahuluan}

Arah pembentukan UU No. 23 Tahun 2004 tentang Penghapusan Kekerasan dalam Rumah Tangga (UU PKDRT) berangkat dari asas bahwa setiap warga negara berhak mendapatkan rasa aman dan bebas dari segala bentuk kekerasan sesuai dengan falsafah Pancasila dan UUD 1945. ${ }^{1}$ Berkaitan dengan kekerasan dalam rumah tangga, Tidak seperti tindak pidana lainnya, tindak pidana kekerasan dalam rumah tangga ini memiliki kekhususan. Kekhususan ini ditunjukkan dengan tipologi pelaku dan korban yang sama, dengan frekuensi jumlah tindak pidana kekerasan yang terjadi bukan hanya satu kali dilakukan, namun berulang-ulang. ${ }^{2}$

Kekerasan dalam rumah tangga terjadi di semua lapisan sosial masyarakat, maupun latar belakang pendidikan. Kekerasan dalam rumah tangga bukan disebabkan oleh situasi ekonomi atau tinggi rendahnya pendidikan seseorang saja, tetapi lebih pada ketidaksetaraan kekuasan antara laki-laki dan perempuan. Pembagian peran sosial terhadap perempuan dan laki-laki menyebabkan terjadinya ketidaksamaan kedudukan dan ketidakadilan terhadap perempuan. ${ }^{3}$

Akhir-akhir ini kekerasan dalam masyarakat tampak semakin meningkat baik kualitas maupun kuantitasnya. Menurut data catatan akhir 2014 Komisi Nasional Anti kekerasan terhadap perempuan juga menunjukkan peningkatan jumlah kasus terhadap perempuan sebanyak 279.760 kasus dibandingkan kasus 2013. Menurut catatan akhir 2014, terdapat 293.220 kasus kekerasan terhadap perempuan sepanjang 2014. Sebanyak 68 persen dari kasus tersebut adalah kekerasan domestik dan rumah tangga (KDRT). ${ }^{4}$

Melihat bahwa kenyataannya kasus kekerasan dalam rumah tangga (KDRT) banyak terjadi. Adapun sistem hukum di Indonesia belum menjamin perlindungan terhadap korban kekerasan yang terjadi dalam lingkup rumah tangga. Hal ini menunjukkan bahwa institusi perkawinan belum menjadi tempat

1 Moert Hadiati Soersosno, Kekerasan dalam Rrumah Tangga dalam Persepektif Yuridis-Viktimologis, Sinar Grafika, Jakarta, 2010, hlm. 1.

2 Berbeda dengan tindak pidana kekerasan lain misalnya: penganiayaan yang umumnya hanya terjadi satu kali dalam satu kejadian.

${ }^{3}$ Moerti Hadiati Soersosno, Kekerasan...., Op.Cit, hlm. 4.

4http://print.kompas.com/baca/2015/04/27/Laporan-KDRT-Meningkat\%2c-Penanganan-BelumOptimal, di akses 30 April 2015. 
yang aman bagi korban kekerasan, banyak korban kekerasan dalam rumah tangga mencari jalan keluar dari kekerasan yang dialaminya melalui perceraian.

UU PKDRT selain mengatur ihwal pencegahan dan perlindungan serta pemulihan terhadap korban kekerasan dalam rumah tangga, juga mengatur secara sepesifik kekerasan yang terjadi dalam rumah tangga dengan unsur-unsur tindak pidana yang berbeda dengan tindak pidana penganiayaan yang diatur dalam KUHP. ${ }^{5}$ Sanksi Pidana dalam UU PKDRT terdapat Pidana Pokok yakni Pidana Penjara atau Denda serta terdapat Pidana Tambahan. ${ }^{6}$ Namun faktanya selama ini berdasarkan data Putusan Pengadilan Negeri Yogyakarta dan Pengadilan Negeri Bantul dari 2010-2014 sanksi pidana yang dijatuhkan hakim hanya menjatuhkan hukuman pidana penjara saja, pidana denda tidak banyak bahkan hampir tidak pernah dijatuhkan apalagi menambahkan pidana tambahan berupa konseling. ${ }^{7}$ Konseling adalah sebagai pemberian bantuan oleh seseorang yang ahli atau orang yang terlatih sedemikian rupa sehingga pemahaman dan kemampuan psikologis diri dapat meningkat dalam memecahkan permasalahan yang dihadapi. ${ }^{8}$

Meskipun sudah dijatuhi pidana penjara KDRT pelaku akan berpotensi terulang kembali dan menimbulkan trauma pada korban dan akan mengakibatkan berakhir hubungan perkawinan mereka dengan perceraian. Pemidanaan saja sering kali tidak berakibat pada terjadinya perimbangan kekuasaan dalam hubungan korban dan pelaku, pendekatan penghukuman seringkali tidak menyentuh aspek prilaku maupun sistem nilai dan norma-norma dalam keluarga, sehingga sekalipun pelaku telah dipidana, namun tetap berpotensi menjadi pelaku kekerasan lagi dan juga pidana tambahan berupa konseling bagi pelaku sebagaimana diatur dalam Pasal 50 huruf b UU PKDRT mempunyai arti yang sangat penting karena merupakan salah satu bentuk intervensi terhadap suami/isteri sebagai pelaku kekerasan dengan maksud untuk melakukan pembinaan dalam rangka memelihara keutuhan rumah tangga yang harmonis dan sejahtera dan jauh dari perceraian mengingat UU PKDRT dalam 2012, hlm. 5.

${ }^{5}$ Guse Praudi, Berbagai Aspek Tindak Pidana Kekerasan dalam Rumah Tangga, Merkid Press, Yogyakarta,

'Pasal 44, 45, 46, 47, 48,49, 50, Undang-Undang PKDRT No. 23 Tahun 2004.

${ }^{7}$ Putusan Pengadilan Negeri Yogyakarta dan Pengadilan Negeri Bantul (2010-2014).

${ }^{8}$ Elly nurhayati, Panduan Untuk Perempuan Korban Kekerasan, Pustaka Pelajar, Yogyakarta, 2000, hlm 2. 
Pasal 4 bertujuan untuk: ${ }^{9} a$. mencegah segala bentuk kekerasan dalam rumah tangga; $b$. Melindungi korban kekerasan dalam rumah tangga; c. menindak pelaku kekerasan dalam rumah tangga; d. memelihara keutuhan rumah tangga yang harmonis dan sejahtera.

Mengingat tingginya angka KDRT maka optimalisasi pidana tambahan berupa sanksi pidana wajib konseling mediasi melalui lembaga konseling merupakan salah satu upaya melindungi dan mencegah agar tindakan KDRT tidak lagi terjadi kembali serta tujuan pemidanaan perlu merunjuk kepada azas dan tujuan dibentuknya UU. Azas dan tujuan ini berupa penghormatan hak asasi manusia, keadilan dan kesetaraan gender, non diskriminasi dan perlindungan korban. Selanjutnya terpulang pada keyakinaan tujuan perkawinanan. Harapannya yaitu membentuk keluarga (rumah tangga) yang bahagia dan kekal berdasarkan keutuhan yang Maha Esa. ${ }^{10}$

\section{Rumusan Masalah}

Berdasarkan latar belakang masalah tersebut maka perumusan masalah dalam penelitian ini adalah: pertama, mengapa hakim cenderung menjatuhkan pidana penjara tanpa mempertimbangkan pidana tambahan berupa konseling sebagai Sanksi Pidana dalam KDRT? Kedua, bagaimana kebijakan aplikatif yang efektif ke depan dalam Penerapan Pidana Tambahan Konseling?

\section{Tujuan Penelitian}

Berdasarkan masalah yang dirumuskan tersebut, penelitian ini bertujuan: pertama, untuk mengetahui mengapa Hakim cenderung menjatuhkan pidana penjara tanpa mempertimbangkan pidana tambahan berupa konseling sebagai sanksi pidana dalam KDRT. Kedua, untuk mengetahui kebijakan aplikatif yang efektif kedepan untuk penerapan pidana tambahan konseling.

9 Pasal 4 UU PKDRT No. 23 Tahun 2004.

${ }^{10}$ Aroma Elmina Martha, Perempuan dan Kekerasan Rumab Tangga di Indonesia dan Malaysia, FH UII Press, Yogyakarta, 2012, hlm. 203. 


\section{Metode Penelitian}

Penelitian ini menggunakan pendekatan normatif, yang didukung data empiris. Metode penelitian hukum empiris digunakan melalui pengambilan data primer di lapangan melalui putusan hakim dan wawancara, kemudian dianalisis. Berkaitan dengan data empiris sebagai data pendukung penelitian ini, pengolahan dan penyajian data penelitian ini menggunakan data primer melalui wawancara kepada Hakim, sedangkan data sekunder diperoleh dari Pengadilan Negeri Yogyakarta dan Pengadilan Negeri Bantul dari 2010-2014.

Alasan memilih Pengadilan Negeri Yogyakarta untuk melihat tingkatan seberapa jauh kasus tindak pidana KDRT yang masuk dan diproses di pengadilan yang merupakan wilayah Ibukota Daerah Istimewa Yogyakarta sebagai wilayah urban sehingga dapat dilihat tingkat tindak pidana KDRT yang terjadi dan kelas IA, dan sebagai pembanding peneliti mengambil dari putusan Pengadilan Negeri Bantul yang merupakan wilayah lebih kecil yakni tingkat kabupaten sehingga diharapkan dapat mewakili dari kedua sisi wilayah tersebut, kelas IIB.

Penelitian ini menggunakan metode analisis penelitian deskriptif kualitatif yaitu penulisan yang dilakukan serangkaian penelitian dengan penggunaan pendekatan kualitatif berupa pengumpulan, analisa dan perumusan data yang berasal dari sumber data baik seperti putusan hakim, UU ataupun lisan seperti wawancara sehingga diharapkan dapat menghasilkan data deskriptif yang bisa menjelaskan mengapa pidana penjara sering diterapkan Hakim. Setelah data dianalisa, dari UU kemudian di hubungkan dengan Putusan Hakim dan ditarik kesimpulan.

\section{Hasil Penelitian dan Pembahasan}

\section{Ketentuan Umum Mengenai Pidana Tambahan Konseling dalam Penyelesaian Tindak Pidana KDRT}

Pidana tambahan adalah pidana yang hanya dapat dijatuhkan di samping pidana pokok Penjatuhan pidana tambahan sifatnya fakultatif artinya hakim tidak selalu harus menjatuhkan suatu pidana tambahan bagi setiap terdakwa 
yang ia adili, melainkan terserah pada pertimbangannya apakah di samping menjatuhkan pidana pokok, ia juga telah bermaksud untuk menjatuhkan suatu pidana tambahan atau tidak. ${ }^{11}$

Apabila undang-undang memungkinkan dijatuhkannya pidana tambahan, maka hakim selalu harus mempertimbangkan, apakah dalam perkara yang dihadapinya dipandang perlu menjatuhkan pidana tambahan tersebut, dengan pengecualian di masa pidana tambahan ini impreratif, sebagaimana tujuan dari pidana tambahan. Sebagian besar bertujuan preventif khusus dan sifat preventif itu begitu besarnya, sehingga sifatnya sebagai pidana akan hilang. ${ }^{12}$

Kedudukan sanksi tambahan dalam hukum pidana berdasarkan Pasal 10 KUHP, Pasal 10 KUHP ini sebagai dasar hukum dalam menjatuhkan pemidanaan oleh hakim. Pasal 10 KUHP membedakan jenis-jenis pidana berdasarkan lima pidana pokok dan tiga pidana tambahan, yaitu: ${ }^{13} 1$. Pidana pokok yang terdiri dari: a) pidana mati; b) pidana penjara; c) pidana kurungan; d) pidana denda, dan e) pidana tutupan. (Berdasarkan pada UU RI No. 20 Tahun 1946 Berita Negara RI tahun kedua No. 24 Tanggal 1 dan 15 November 1946). 2. pidana tambahan yang terdiridari: a) pencabutan hak-hak tertentu; b) perampasan barang-barang tertentu, dan c) pengumuman putusan hakim.

Pada UU PKDRT No. 23 Tahun 2004 Pidana yang dijatuhkan pada pelaku kekerasan dalam rumah tangga adalah pidana penjara atau denda, sedangkan pidana tambahan, berbeda dengan Pasal 10 KUHP, dalam Pasal 50 UndangUndang No. 23 Tahun 2004 disebutkan pidana tambahan bagi pelaku kekerasan dalam rumah tangga adalah: ${ }^{14}$ a. Pembatasan gerak pelaku baik yang bertujuan untuk menjatuhkan pelaku dari korban dalam jarak dan waktu tertentu, maupun pembatasan hak-hak tertentu dari pelaku; b. . Penetapan pelaku mengikuti program konseling dibawah pengawasan lembaga tertentu.

82.

${ }^{11}$ P.A.F. Lamintang dan Theo Lamintang, Hukum Penitensier Indonesia, Sinar Grafika, Jakarta, 2012, hlm.

12 Hermien Hardiati Koeswadji, Perkembangan Macam-Macam Pidana dalam Rangka Perkembangan Hukum Pidana, PT. Citra Aditya Bakti, Bandung, 1995, hlm. 40.

13 Pasal 10 Kitab Undang-undang Hukum Pidana (KUHP)

${ }^{14}$ Pasal 50 Undang-Undang PKDRT No. 23 Tahun 2004. 


\section{Pertimbangan Hakim dalam Menjatuhkan Pidana Penjara}

Dengan diundangkannya Undang-Undang No. 23 Tahun 2004 maka kasus kekerasan dalam rumah tangga yang dilakukan oleh pelaku tindak pidana KDRT terhadap istri atau suami sudah banyak yang diproses ke pengadilan atau disidangkan. Hal ini menunjukkan kesadaran hukum bahwa kekerasan dalam rumah tangga bukan lagi merupakan hal yang harus ditutup-tutupi atau merupakan aib keluarga.

Tindak Pidana dan Sanksi Pidana Penjara yang dijatuhkan Hakim di Pengadilan Negeri Yogyakarta dan Pengadilan Negeri Bantul (2010-2014)

\begin{tabular}{|c|c|c|c|}
\hline No & Putusan & Dakwaan & Sanksi Pidana \\
\hline \multicolumn{4}{|c|}{ Pengadilan Negeri Yogyakarta } \\
\hline 1 & 216/Pid.Sus/2010/PN.Yk & $\begin{array}{l}\text { Pasal } 44 \text { ayat (4) UU PKDRT } \\
\text { No. } 23 \text { Tahun } 2004\end{array}$ & Penjara 4 bulan \\
\hline 2 & 440/Pid.Sus/2012/PN.Yk & $\begin{array}{l}\text { Pasal } 44 \text { ayat (4) UU PKDRT } \\
\text { No. } 23 \text { Tahun } 2004\end{array}$ & Penjara 3 bulan \\
\hline 3 & 386/Pid.Sus/2012/PN.Yk & $\begin{array}{l}\text { Pasal } 44 \text { ayat (4) UU PKDRT } \\
\text { No. } 23 \text { Tahun } 2004\end{array}$ & Penjara 4 bulan \\
\hline 4 & 371/Pid.Sus/2012/PN.Yk & $\begin{array}{l}\text { Pasal } 44 \text { ayat (4) UU PKDRT } \\
\text { No. } 23 \text { Tahun } 2004\end{array}$ & 3bulan dan15 hari \\
\hline 5 & 285/Pid.Sus/2012/PN.Yk. & $\begin{array}{l}\text { Pasal } 44 \text { ayat (4) UU PKDRT } \\
\text { No. } 23 \text { Tahun } 2004\end{array}$ & 3 bulandan 7 hari \\
\hline 6 & 208/Pid.Sus/2012/PN.Yk. & $\begin{array}{l}\text { Pasa } 144 \text { ayat (4) KUHAP jo } \\
\text { Pasal } 5 \text { huruf a UU PKDRT } \\
\text { No. } 23 \text { Tahun } 2004\end{array}$ & $\begin{array}{l}4 \text { bulanpercobaan } 6 \\
\text { bulan }\end{array}$ \\
\hline 7 & 370/Pid.Sus/2013/PN.Yk. & $\begin{array}{l}\text { Pasal } 44 \text { ayat (4) UU PKDRT } \\
\text { No. } 23 \text { Tahun } 2004\end{array}$ & Penjara 4 bulan \\
\hline 8 & 155/Pid.Sus/2013/ PN.YK & $\begin{array}{l}\text { Pasal } 44 \text { ayat (1) UU PKDRT } \\
\text { No. } 23 \text { Tahun } 2004\end{array}$ & penjara 5 bulan \\
\hline 9 & 82/PID.SUS/2014/PN.YK & $\begin{array}{l}\text { Pasal } 44 \text { ayat (1) UU PKDRT } \\
\text { No. } 23 \text { Tahun } 2004\end{array}$ & $\begin{array}{l}\text { Penjara } 3 \text { bulan } \\
\text { dan } 20 \text { hari }\end{array}$ \\
\hline \multicolumn{4}{|c|}{ Pengadilan Negeri Bantul } \\
\hline 1 & 177/Pid.Sus/2014/PN Btl. & $\begin{array}{l}\text { Pasal } 44 \text { ayat (4) UU PKDRT } \\
\text { No. } 23 \text { Tahun } 2004\end{array}$ & $\begin{array}{l}\text { PidanaPenjara } \\
\text { bulan }\end{array}$ \\
\hline 2 & 163/Pid.Sus/2014/PN Btl. & $\begin{array}{l}\text { Pasal } 44 \text { ayat (4) UU PKDRT } \\
\text { No. } 23 \text { Tahun } 2004\end{array}$ & $\begin{array}{l}\text { PidanaPenjara } 2 \\
\text { bulan }\end{array}$ \\
\hline 3 & 98/Pid.Sus/2014/PN Btl. & $\begin{array}{l}\text { Pasal } 44 \text { ayat (4) UU PKDRT } \\
\text { No. } 23 \text { Tahun } 2004\end{array}$ & Penjara 1 Bulan \\
\hline 4 & 258/PID.SUS/PN.BTL & $\begin{array}{l}\text { Pasal } 44 \text { ayat (1) UU PKDRT } \\
\text { No. } 23 \text { Tahun } 2004 \text { atau Pasal } \\
351 \text { ayat (1) KUHP }\end{array}$ & $\begin{array}{l}\text { Penjara } 2 \text { Bulan } 15 \\
\text { Hari }\end{array}$ \\
\hline 5 & 197/Pid.Sus/2013/PN.Btl & $\begin{array}{l}\text { Pasal } 5 \text { huruf a Jo. Pasal } 44 \\
\text { ayat (4) UU PKDRT No. } 23 \\
\text { Tahun } 2004\end{array}$ & $\begin{array}{l}\text { Penjara } 8 \text { Bulan, } \\
\text { bersyarat }\end{array}$ \\
\hline
\end{tabular}




\begin{tabular}{|l|l|l|l|}
\hline 6 & $156 /$ Pid.Sus/2013/PN.Btl & $\begin{array}{l}\text { Pasal 5 huruf a Jo. Pasal 44 } \\
\text { ayat 4) UU PKDRT No. 23 } \\
\text { Tahun 2004 }\end{array}$ & Penjara 2 Bulan \\
\hline 7 & $79 /$ Pid.Sus/2013/PN.Btl & $\begin{array}{l}\text { Pasal 5 huruf a Jo. Pasal 44 } \\
\text { ayat (4) UU PKDRT No. 23 } \\
\text { Tahun 2004 }\end{array}$ & Penjara 3 Bulan \\
\hline 8 & $74 /$ Pid.Sus/2013/PN.Btl & $\begin{array}{l}\text { Pasal 44 ayat (1) ayat (4) UU } \\
\text { PKDRT No. 23 Tahun 2004 }\end{array}$ & $\begin{array}{l}\text { Penjara 2 Bulan 15 } \\
\text { Hari }\end{array}$ \\
\hline 9 & $227 /$ Pid.Sus/2013/PN.Btl & $\begin{array}{l}\text { Pasal 44 ayat (4) UU PKDRT } \\
\text { No. 23 Tahun 2004 }\end{array}$ & Penjara 2 Bulan \\
\hline 10 & $44 /$ Pid.Sus/2012/PN.Btl & $\begin{array}{l}\text { Pasal 44 ayat (4) UU PKDRT } \\
\text { No. 23 Tahun 2004 }\end{array}$ & Penjara 2 Bulan \\
\hline 11 & $21 /$ Pid.Sus/2011/PN.Btl & $\begin{array}{l}\text { Pasal 44 ayat (4) UU PKDRT } \\
\text { No. 23 Tahun 2004 Penjara 2 Bulan }\end{array}$ & $\begin{array}{l}\text { Pasal 44 ayat (4) UU PKDRT } \\
\text { No. 23 Tahun 2004 Penjara 3 Bulan }\end{array}$ \\
\hline 12 & $108 /$ Pid.Sus/2011/PN.Btl & $\begin{array}{l}\text { Pasal 44 ayat (4) UU PKDRT } \\
\text { No. 23 Tahun 2004 }\end{array}$ & Penjara 2 Bulan \\
\hline 13 & $163 /$ Pid.Sus/2010/PN.Btl & $\begin{array}{l}\text { Pasal 356 KUHP jo Pasal 44 } \\
\text { ayat (1) dan ayat (4) UU } \\
\text { PKDRT No. 23 Tahun 2004 }\end{array}$ & Penjara 3 Bulan \\
\hline 14 & $267 /$ Pid.Sus/2010/PN.Btl & \\
\hline
\end{tabular}

Sumber: Putusan Pengadilan Negeri Yogyakarta dan Pengadilan Negeri Bantul dari Tahun 20102014

Berdasarkan hasil wawancara dengan Hakim Pengadilan Negeri Yogyakarta, ${ }^{15}$ alasan dominan hakim menjatuhkan pidana penjara dikarenakan Para hakim masih menganggap bahwa dengan pertimbangan yang seksama, mayoritas masyarakat Indonesia banyak dilakukan oleh laki-laki dan hukuman yang dianut masih banyak menerapkan pidana penjara, pidana penjara masih dapat digunakan sebagai sarana yang memadai untuk penanggulangan tindak pidana KDRT, Pidana penjara dijatuhkan karena diancamkan dalam hukum pidana.

Pidana penjara dijatuhkan karena dapat diandalkan dalam penanggulangan kejahatan di Indonesia. Sebelum menjatuhkan pidana penjara, hakim selalu mempertimbangkan faktor-faktor yang memberatkan dan meringankan terpidana untuk menentukan lamanya pidana penjara (strafmaat). Belum tersedia jenis pidana yang dapat dijadikan alternatif pidana penjara, maka hakim akhirnya tetap memilih pidana penjara untuk dijatuhkan terhadap pelaku tindak pidana KDRT, dan Jaksa Penuntut Umum (JPU) selama ini banyak

15 Wawancara dengan Asep Permana, S.H., M.,H. Hakim Pengadilan Negeri Yogyakarta, tanggal 29 Juni 2015, di Ruang Hakim Pengadilan Negeri Yogyakarta. 
mendakwakan dengan pidana penjara, selama ini Jaksa Penuntut Umum (JPU) memilih ancaman pidana penjara karena hukum pidana mengatur dan mengancam tindak pidana tersebut dengan pidana penjara.

Sedangkan menurut, Bayu Soho Rahardjo, S.H., (Hakim Pengadilan Negeri Bantul), ${ }^{16}$ hakim lebih dominan menjadikan pidana penjara yang sering diterapkan dikarenakan tindak pidana KDRT berbeda dengan perlindungan anak sehingga tidak dimungkinkan diversi, di pengadilan lebih banyak menerapkan punisment dari pada treatment, treatment sulit dilakukan karena ada syarat-syarat yang harus dipenuhi diantaranya saling memaafkan antara keduanya serta diperlukan surat pernyataan dan juga kasus KDRT yang dilaporkan korban, korban sudah mengalami KDRT jauh sebelum ia berani melaporkan tindak KDRT tersebut, sehingga KDRT yang dialaminya adalah akumulasi dari rasa yang ditahan selama ini.

Hampir sebagian besar putusan yang dijatuhkan oleh hakim adalah pidana penjara yang rata-rata di bawah 3 (tiga) tahun bahkan di bawah 1 (satu) tahun. Sanksi pidana ini disebabkan karena putusan yang dijatuhkan sebagian besar menggunakan Pasal 44 ayat (1) dan Pasal 44 ayat (4). Kedua Pasal ini memberikan ancaman sanksi di bawah 5 tahun atau denda Rp. 15.000.000,- (Pasal 44 ayat (1) dan dipidana 4 bulan atau denda paling banyak Rp. 5.000.000,-. Faktanya ada putusan yang menggunakan Pasal 44 ayat (4) dijatuhi pidana percobaan.

Analisis putusan sanksi pidana menunjukkan hampir sebagian besar putusan KDRT menggunakan Pasal 44 ayat (1) dan Pasal 44 ayat (4) dominan digunakan hakim dalam memutuskan perkara KDRT meskipun tidak banyak, KUHP juga masih digunakan, khususnya Pasal 356.

Dalam putusan sanksi pidana KDRT cenderung penjara ringan, hal tersebut disebabkan oleh karena hukum bukan dijadikan sebagai ajang membalas dendam tetapi hukum itu sendiri untuk menertibkan dan mendidik serta putusan yang dikeluarkan oleh hakim juga bertujuan untuk keseimbangan sosiologis di masyarakat.

${ }^{16}$ Wawancara dengan Bayu Soho Rahardjo, S.H., Hakim Pengadilan Negeri Bantul, tanggal 5 Agustus 2015, di Ruang Mediasi Pengadilan Negeri Bantul. 
Dalam penjatuhan pidana terhadap terdakwa dapat pula dilihat dari aspek kesalahan terdakwa dan keadilan bagi korban serta keadaan-keadaan yang meringankan maupun memberatkan bagi terdakwa kekerasan dalam rumah tangga, karena pada dasarnya terjadinya suatu kekerasan dalam rumah tangga disebabkan oleh ketidak harmonisan dalam suatu keluarga. Sehingga terjadinya suatu tindak KDRT tersebut tidak hanya ada keinginan dari pelaku namun korban juga turut berperan dalam terjadinya KDRT tersebut. ${ }^{17}$

Hal yang Meringankan dan Memberatkan dalam Menjatuhkan Pidana pada Pengadilan Negeri Yogyakarta dan Pengadilan Negeri Bantul

\begin{tabular}{|c|c|c|c|c|}
\hline No & Putusan & Hal-hal yang Meringankan & $\begin{array}{l}\text { Hal-hal yang } \\
\text { memberatkan }\end{array}$ & $\begin{array}{l}\text { Sanksi } \\
\text { Pidana }\end{array}$ \\
\hline \multicolumn{5}{|c|}{ Pengadilan Negeri Yogyakarta } \\
\hline 1 & $\begin{array}{l}\text { 216/Pid.Sus/ } \\
\text { 2010/PN.Yk }\end{array}$ & $\begin{array}{l}\text { Terdakwa telah menyesali } \\
\text { perbuatannya dan belum } \\
\text { pernah dihukum. }\end{array}$ & $\begin{array}{lr}\text { Terdakwa } & \text { sebagai } \\
\text { kepala rumah } \\
\text { tangga } \\
\text { melindungi } \\
\text { justru melakukan } \\
\text { penganiayaan }\end{array}$ & $\begin{array}{l}\text { Penjara } \\
\text { bulan }\end{array}$ \\
\hline 2 & $\begin{array}{l}\text { 440/Pid.Sus/ } \\
\text { 2012/PN.Yk }\end{array}$ & - & - & $\begin{array}{l}\text { Penjara } \\
\text { bulan. }\end{array}$ \\
\hline 3 & $\begin{array}{l}\text { 386/Pid.Sus/ } \\
\text { 2012/PN.Yk }\end{array}$ & $\begin{array}{lr}\text { Terdakwa } & \text { sopan } \\
\text { dipersidangan dan } & \text { belum } \\
\text { pernah dihukum } & \end{array}$ & $\begin{array}{lr}\text { Terdakwa } & \text { sebagai } \\
\text { kepala } & \text { rumah } \\
\text { tangga } & \text { tidak } \\
\text { melindungi istrinya }\end{array}$ & $\begin{array}{l}\text { Penjara } \\
\text { bulan }\end{array}$ \\
\hline 4 & $\begin{array}{l}\text { 371/Pid.Sus/ } \\
\text { 2012/PN.Yk }\end{array}$ & $\begin{array}{l}\text { Terdakwa telah menyesali } \\
\text { perbuatannya dan belum } \\
\text { pernah dihukum serta Saksi } \\
\text { korban telah mema'afkan } \\
\text { terdakwa dan keduanya telah } \\
\text { berjanji untuk menjalin } \\
\text { hubungan rumah tangganya }\end{array}$ & \begin{tabular}{lrr} 
Tidak & \multicolumn{2}{r}{ ditemukan } \\
ada & hal & yang \\
memberatkan &
\end{tabular} & $\begin{array}{l}\text { Penjara } 3 \\
\text { bulandan } \\
15 \text { hari }\end{array}$ \\
\hline 5 & $\begin{array}{l}\text { 285/Pid.Sus/ } \\
\text { 2012/PN.Yk. }\end{array}$ & $\begin{array}{l}\text { Terdakwa mengakui terus } \\
\text { terang perbuatannya } \\
\text { Terdakwa menyesal dan } \\
\text { berjanji tidak akan mengulangi } \\
\text { perbuatannya, } \\
\text { Terdakwa belum pernah } \\
\text { dihukum }\end{array}$ & $\begin{array}{l}\text { Perbuatan terdakwa } \\
\text { mengakibatkan } \\
\text { penderitaan bagi } \\
\text { orang lain }\end{array}$ & $\begin{array}{l}\text { Penjara } 3 \\
\text { bulandan } \\
7 \text { hari }\end{array}$ \\
\hline 6 & $\begin{array}{l}\text { 208/Pid.Sus/ } \\
\text { 2012/PN.Yk. }\end{array}$ & $\begin{array}{l}\text { Terdakwa mengakui terus } \\
\text { terang perbuatannya, telah } \\
\text { menyesali kesalahannya dan } \\
\text { berjanji tidak akan mengulagi }\end{array}$ & $\begin{array}{l}\text { Perbuatan Terdakwa } \\
\text { meresahkan } \\
\text { masyarakat; } \\
\text { Terdakwa tega }\end{array}$ & $\begin{array}{l}\text { Penjara } 4 \\
\text { bulan } \\
\text { percobaan } \\
6 \text { bulan }\end{array}$ \\
\hline
\end{tabular}

${ }^{17}$ Andi Hamzah, Sistem Pidana dan Pemidanaan Indonesia, Dari Retribusi ke Reformasi. Jakarta: PT Pradnya Paramita, 1986, hlm. 53. 


\begin{tabular}{|c|c|c|c|c|}
\hline & & $\begin{array}{l}\text { perbuatannya lagi, Terdakwa } \\
\text { belum pernah dihukum }\end{array}$ & $\begin{array}{l}\text { melakukan } \\
\text { kekerasan kepada } \\
\text { seorang perempuan, } \\
\text { ibu dari anak-anak } \\
\text { terdakwa }\end{array}$ & \\
\hline 7 & $\begin{array}{l}\text { 370/Pid.Sus/ } \\
\text { 2013/PN.Yk. }\end{array}$ & $\begin{array}{l}\text { Terdakwa merasa menyesal } \\
\text { atas perbuatannya, Terdakwa } \\
\text { belum pernah dihukum }\end{array}$ & $\begin{array}{lr}\text { perbuatan Terdakwa } \\
\text { sangat tidak } & \text { layak } \\
\text { dilakukan } & \text { oleh } \\
\text { seorang } & \text { suami } \\
\text { terhadap } & \text { isterinya } \\
\text { yang sedang } & \text { hamil, } \\
\text { yang } & \text { seharusnya } \\
\text { patut } & \text { Terdakwa } \\
\text { sayangi } & \text { dan } \\
\text { lindungi } & \text { saksi } \\
\text { korban sudah } & \text { tidak } \\
\text { dapat } & \text { lagi } \\
\text { memaafkan } & \\
\text { Terdakwa } & \text { sampai } \\
\text { kapanpun } & \\
\end{array}$ & $\begin{array}{l}\text { Penjara } \\
\text { bulan }\end{array}$ \\
\hline 8 & $\begin{array}{l}\text { 155/Pid.Sus/ } \\
\text { 2013/ PN.YK }\end{array}$ & $\begin{array}{l}\text { Terdakwa menyesal dan } \\
\text { berjanji tidak akan mengulangi } \\
\text { perbuatannya, } \\
\text { Terdakwa bersikap sopan dan } \\
\text { mengaku terus terang } \\
\text { perbuatannya }\end{array}$ & $\begin{array}{l}\text { Perbuatan terdakwa } \\
\text { telah dilakukan } \\
\text { berulang kali }\end{array}$ & $\begin{array}{l}\text { Penjara } \\
\text { bulan }\end{array}$ \\
\hline 9 & $\begin{array}{l}\text { 82/PID.SUS/ } \\
\text { 2014/PN.YK }\end{array}$ & $\begin{array}{lr}\text { Terdakwa menyesal dan } & \text { dak } \\
\text { berjanji tidak akan mengulangi } \\
\text { perbuatannya,Terdakwa telah } \\
\text { dimaafkan oleh isterinya dan } \\
\text { diterima kembali untuk } \\
\text { membina } & \text { rumah } \\
\text { tangga,Terdakwa } & \text { masih } \\
\text { mencintai isteri dan anaknya } \\
\text { dan akan kembali berkumpul } \\
\text { dengan isteri dan anaknya } \\
\text { Terdakwa } \\
\text { tanggungan mempunyai } \\
\begin{array}{l}\text { Terdakwa belum } \\
\text { dihukum }\end{array}\end{array}$ & $\begin{array}{l}\text { Terdakwa telah } \\
\text { melakukan } \\
\text { perbuatan main } \\
\text { Hakim sendiri ; } \\
\text { Terdakwa melukai } \\
\text { telah isterinya yang } \\
\text { seharusnya dicintai } \\
\text { dan dilindungi }\end{array}$ & $\begin{array}{l}\text { Penjara } 3 \\
\text { bulan dan } \\
20 \text { hari }\end{array}$ \\
\hline \multicolumn{5}{|c|}{ Pengadilan Negeri Bantul } \\
\hline 1 & $\begin{array}{l}\text { 177/Pid.Sus/ } \\
\text { 2014/PN Btl. }\end{array}$ & $\begin{array}{l}\text { Terdakwa berlaku sopan di } \\
\text { persidangana dan menyesali } \\
\text { perbuatannya }\end{array}$ & $\begin{array}{l}\text { Perbuatan terdakwa } \\
\text { merugikan } \text { orang } \\
\text { lain }\end{array}$ & $\begin{array}{l}\text { Penjara } \\
\text { bulan }\end{array}$ \\
\hline 2 & $\begin{array}{l}\text { 163/Pid.Sus/ } \\
\text { 2014/PN Btl. }\end{array}$ & $\begin{array}{l}\text { Terdakwa telah menyesali } \\
\text { perbuatannya dan belum } \\
\text { pernah dihukum serta } \\
\text { tenaganya masih diperlukan } \\
\text { dijajaran kepolisian }\end{array}$ & $\begin{array}{lr}\text { Terdakwa } & \text { sebagai } \\
\text { penegak } & \text { hukum } \\
\text { seharusnya } & \text { bisa } \\
\text { memberikan } & \text { contoh } \\
\text { yang baik } & \end{array}$ & $\begin{array}{ll}\text { Penjara } & 2 \\
\text { bulan } & \end{array}$ \\
\hline
\end{tabular}




\begin{tabular}{|c|c|c|c|c|}
\hline 3 & $\begin{array}{l}\text { 98/Pid.Sus/2 } \\
\text { 014/PN Btl. }\end{array}$ & $\begin{array}{l}\text { Terdakwa telah menyesali } \\
\text { perbuatannya dan belum } \\
\text { pernah dihukum. }\end{array}$ & \begin{tabular}{lrr} 
Tidak & \multicolumn{2}{r}{ ditemukan } \\
ada hal yang \\
memberatkan
\end{tabular} & $\begin{array}{l}\text { Penjara } \\
\text { Bulan }\end{array}$ \\
\hline 4 & $\begin{array}{l}\text { 258/PID.SUS } \\
\text { / PN.BTL }\end{array}$ & $\begin{array}{l}\text { Terdakwa belum pernah } \\
\text { dihukum, terdakwa telah } \\
\text { meminta maaf dan terdakwa } \\
\text { menyesali perbuatannya. }\end{array}$ & $\begin{array}{l}\text { Perbuatan terdakwa } \\
\text { menimbulkan rasa } \\
\text { sakit pada saksi } \\
\text { korban }\end{array}$ & $\begin{array}{lr}\text { Penjara } & 2 \\
\text { Bulan } & 15 \\
\text { Hari }\end{array}$ \\
\hline 5 & $\begin{array}{l}\text { 197/Pid.Sus/ } \\
\text { 2013/PN.Btl }\end{array}$ & $\begin{array}{l}\text { Terdakwa belum pernah } \\
\text { dihukum, terdakwa sopan } \\
\text { dipersidangan terdakwa } \\
\text { menyesali perbuatannya }\end{array}$ & $\begin{array}{l}\text { Berbuatan terdakwa } \\
\text { merugikan istri, } \\
\text { perbuatan terdakwa } \\
\text { bertentangan } \\
\text { dengan nilai-nilai } \\
\text { agama dan moral }\end{array}$ & $\begin{array}{l}\text { Penjara } 8 \\
\text { Bulan, } \\
\text { bersyarat }\end{array}$ \\
\hline 6 & $\begin{array}{l}\text { 156/Pid.Sus/ } \\
\text { 2013/PN.Btl }\end{array}$ & $\begin{array}{l}\text { Terdakwa mengakui terus } \\
\text { terang perbuatannya dan } \\
\text { menyesali }\end{array}$ & $\begin{array}{lr}\text { Terdakwa } & \text { sebagai } \\
\text { kepala } & \text { rumah } \\
\text { tangga } & \text { tidak } \\
\text { melindungi istrinya }\end{array}$ & $\begin{array}{l}\text { Penjara } \\
\text { Bulan }\end{array}$ \\
\hline 7 & $\begin{array}{l}\text { 79/Pid.Sus/2 } \\
\text { 013/PN.Btl }\end{array}$ & $\begin{array}{l}\text { Terdakwa belum pernah } \\
\text { dihukum, terdakwa sopan } \\
\text { dipersidangan terdakwa } \\
\text { menyesali perbuatannya }\end{array}$ & $\begin{array}{l}\text { Sifat dari perbuatan } \\
\text { terdakwa } \\
\text { meresahkan orang } \\
\text { lain }\end{array}$ & $\begin{array}{l}\text { Penjara } \\
\text { Bulan }\end{array}$ \\
\hline 8 & $\begin{array}{l}\text { 74/Pid.Sus/2 } \\
\text { 013/PN.Btl }\end{array}$ & $\begin{array}{l}\text { Terdakwa mengakui terus } \\
\text { terang perbuatannya, telah } \\
\text { menyesali kesalahannya dan } \\
\text { berjanji tidak akan mengulagi } \\
\text { perbuatannya lagi, Terdakwa } \\
\text { belum pernah dihukum }\end{array}$ & $\begin{array}{l}\text { Perbuatan terdakwa } \\
\text { tidak sesuai dengan } \\
\text { kodrat sebagai } \\
\text { kepala rumah } \\
\text { tangga yang harus } \\
\text { mengayomi istrinya }\end{array}$ & $\begin{array}{lr}\text { Penjara } & 2 \\
\text { Bulan } & 15 \\
\text { Hari } & \end{array}$ \\
\hline 9 & $\begin{array}{l}\text { 227/Pid.Sus/ } \\
\text { 2013/PN.Btl }\end{array}$ & $\begin{array}{l}\text { Terdakwa berlaku sopan } \\
\text { dipersidangan, belum pernah } \\
\text { di hukum dan saksi korban } \\
\text { telah memaafkan terdakwa } \\
\text { serta terdakwa pada dasarnya } \\
\text { juga merupakan korban dari } \\
\text { KDRT saksi korban }\end{array}$ & $\begin{array}{lr}\text { Perbuatan } & \text { terdakwa } \\
\text { membuat } & \text { saksi } \\
\text { korban } & \text { merasa } \\
\text { trauma } & \end{array}$ & $\begin{array}{l}\text { Penjara } 2 \\
\text { Bulan } \\
\text { Percobaan } \\
4 \text { Bulan }\end{array}$ \\
\hline 10 & $\begin{array}{l}\text { 44/Pid.Sus/2 } \\
\text { 012/PN.Btl }\end{array}$ & $\begin{array}{l}\text { Terdakwa merasa menyesal } \\
\text { atas perbuatannya, Terdakwa } \\
\text { belum pernah dihukum }\end{array}$ & $\begin{array}{l}\text { Perbuatan tersangka } \\
\text { meresahkzan } \\
\text { masyarakat }\end{array}$ & $\begin{array}{l}\text { Penjara } \\
\text { Bulan }\end{array}$ \\
\hline 11 & $\begin{array}{l}\text { 21/Pid.Sus/2 } \\
\text { 011/PN.Btl }\end{array}$ & $\begin{array}{l}\text { Terdakwa mengakui terus } \\
\text { teraang dan menyesali } \\
\text { perbuatannya }\end{array}$ & $\begin{array}{l}\text { Perbuatan terdakwa } \\
\text { menimbulkan rasa } \\
\text { trauma bagi saksi } \\
\text { korban }\end{array}$ & $\begin{array}{l}\text { Penjara } \\
\text { Bulan }\end{array}$ \\
\hline 12 & $\begin{array}{l}\text { 108/Pid.Sus/ } \\
\text { 2011/PN.Btl }\end{array}$ & 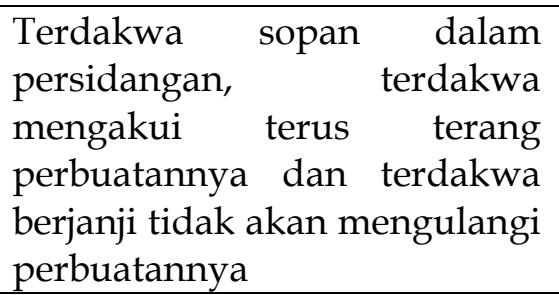 & $\begin{array}{l}\text { Perbuatan terdakwa } \\
\text { mengakibatkan saksi } \\
\text { korban mengalami } \\
\text { luka-luka }\end{array}$ & $\begin{array}{l}\text { Penjara } \\
\text { Bulan }\end{array}$ \\
\hline 13 & $\begin{array}{l}\text { 163/Pid.Sus/ } \\
\text { 2010/PN.Btl }\end{array}$ & $\begin{array}{l}\text { Terdakwa merasa menyesal } \\
\text { atas perbuatannya, Terdakwa } \\
\text { belum pernah dihukum }\end{array}$ & $\begin{array}{l}\text { Perbuatan terdakwa } \\
\text { mengakibatkan } \\
\text { korban terluka }\end{array}$ & $\begin{array}{l}\text { Penjara } \\
\text { Bulan }\end{array}$ \\
\hline
\end{tabular}




\begin{tabular}{|l|l|l|l|l|}
\hline 14 & 267/Pid.Sus/ & $\begin{array}{l}\text { Terdakwa mengaku belum } \\
\text { pernah dihukum, terdakwa } \\
\text { 2010/PN.Btl } \\
\text { bersikap sopan selama } \\
\text { persidangan, terdakwa } \\
\text { mempunyai tanggung jawab } \\
\text { dikeluarganya }\end{array}$ & $\begin{array}{l}\text { dengan pertentangan program } \\
\text { pemerintah }\end{array}$ & Bulan \\
\end{tabular}

Sumber: Putusan Pengadilan Negeri Yogyakarta dan Pengadilan Negeri Bantul Tahun 2010-2014

Jika dikaji dengan tujuan pemidanan maka masuk ke dalam pertimbangan hakim untuk memberi kesempatan bagi pelaku memperbaiki dirinya (deterrence). Sedangkan pada hal-hal yang memberatkan cenderung pada tujuan pemidanaan retributif, misalnya: perbuatan terdakwa meresahkan masyarakat, supaya terdakwa tidak mengulangi perbuatannya. ${ }^{18}$

Berdasarkan analisis diatas dapat disimpulkan bahwa pertimbangan hakim dalam menjatuhkan pidana penjara adalah: 1. pidana penjara masih dianggap dapat digunakan sebagai sarana yang memadai untuk menanggulangi tindak pidana KDRT; 2. menurut para Hakim belum tersedianya jenis sanksi pidana alternatif lain selain pidana penjara yang lebih efektif jika pidana selain itu diterapkan; 3. jaksa menuntut dengan pidana penjara saja; 4. di Pengadilan penerapan sanksi tindakan berupa mengikuti program mengikuti program konseling belum banyak dikenal karena menurut hakim banyak ada syarat-syarat yang harus dipenuhi.

\section{Pertimbangan Pidana Tambahan Konseling yang Jarang Dilaksanakan}

Berdasarkan data putusan hakim dari 2010-2014 di Pengadilan Negeri Yogyakarta dan Pengadilan Negeri Bantul belum ditemukan putusan hakim menjatuhkan pidana tambahan berupa mengikuti program konseling. Berdasarkan wawancara dengan Hakim Pengadilan Negeri Yogyakarta, ${ }^{19}$ alasan hakim belum menerapkan konseling karena ada beberapa pertimbangan, 1) instrumennya belum jelas; 2) lembaganya belum jelas dan kondisinya belum siap sementara harus ada lembaga (panitia); 3) undang-undang PKDRT tidak pernah diterapkan secara utuh; 4) perlindungan korban belum efektif; 5) sosialisi belum dilaksanakan; 6) eksekutif dan legislatif belum memberikan perangkat; 7) jaksa

\footnotetext{
${ }^{18}$ Data pengelompokkan tujuan pemidanaan seluruh putusan ini telah diolah sebelumnya.

${ }^{19}$ Wawancara dengan Asep Permana, S.H., M.,H. Hakim Pengadilan Negeri Yogyakarta.
} 
belum pernah menuntut dengan pidana tambahan berupa mengikuti program konseling. Namun, Asep menyampaikan ide bahwa mengedepankan konseling ini cukup bagus dan harus segera bisa diterapkan. Hanya saja konseling ini masuk pidana tambahan haruslah berdasarkan pembuktian, jika deliknya terbukti jika tidak ada alasan pembenar maka akan bermasalah, undang-undang itu das sollen, harus ada kesepakatan di DPR dan juga perangkatnya harus dibenahi.

Sedangkan menurut Hakim Pengadilan Negeri Bantul20 alasan hakim belum menerapkan konseling adalah aturan konseling yang belum dijelaskan secara rinci di dalam UU PKDRT sehingga membuat penegak hukum belum menerapkan konseling tersebut dan juga kekurangannya ada pada lembaga konseling itu sendiri, yang belum jelas badan mana yang ditunjuk dan biayanya juga belum jelas dibebankan pada siapa. Walaupun begitu beliau sepakat jika implementasi konseling ini diterapkan dalam tindak pidana KDRT karena memang sudah diatur dalam UU PKDRT namun harus dilihat dari kasus perkasus dan juga dilihat dari kesungguhan terdakwa untuk tidak mengulangi perbuatannya dengan melakukan KDRT kembali, dan harus diperjelas lembaga mana yang berwenang yang sudah langsung ditunjuk dinas apa yang terkait, biaya dibebankan kesiapa, berapa lama proses konseling, perlu ada pedoman yang jelas.

Bahwa belum ada putusan pidana tambahan sebagaimana diatur Pasal 50 huruf $\mathrm{b}$ UU PKDRT, Hakim belum menerapkan pidana tambahan berupa konseling perubahan perilaku bagi pelaku kekerasan dalam rumah tangga, karena hakim dalam menjatuhkan putusan berdasarkan dari tuntutan dari Jaksa kepada terdakwa, Jaksa belum menggunakan Pasal 50 huruf b, dalam menuntut pelaku. Sosialisasi mengenai adanya lembaga yang dapat memberikan layanan konseling kepada pelaku, sesuai Pasal 50 huruf b UU PKDRT belum pernah ada baik dari Pemerintah Pusat maupun Pemerintah Daerah. Hakim belum mendapatkan informasi mengenai lembaga yang memberikan layanan, belum ada sosialisasi dari Pemerintah lembaga mana yang siap dan dapat ditunjuk sebagai pelaksana pidana tambahan berupa konseling. Sampai saat ini belum ada

${ }^{20}$ Wawancara dengan Bayu Soho Rahardjo, S.H., Hakim Pengadilan Negeri Bantul. 
tata cara dan mekanisme pengawasan terhadap pelaksanaan pidana tambahan, yang berbeda dengan pelaku kasus narkoba yang direhabilitasi dan dapat dipantau serta diawasi oleh Jaksa.

Berdasarkan fakta yang ada, lembaga penyedia layanan konseling kepada pelaku kekerasan belum diselenggarakan oleh Pengadilan Negeri Yogyakarta dan Pengadilan Negeri Bantul. Keadaan tersebut merupakan salah satu kendala bagi hakim bila menerapkan pidana tambahan berupa konseling kepada pelaku.

Dari data di Pengadilan Negeri Yogyakarta dan Pengadilan Negeri Bantul dan hasil wawancara dengan Hakim Pengadilan Negeri Yogyakarta dan Pengadilan Negeri Bantul dapat disimpulkan bahwa pertimbangan hakim belum menerapkan pidana tambahan berupa konseling perubahan perilaku bagi pelaku kekerasan tindak pidana KDRT adalah karena: 1. belum pernah ada tuntutan/dakwaan dari Jaksa yang menggunakan Pasal 50 huruf b UndangUndang Nomor 23 Tahun 2004 tentang Penghapusan Kekerasan Dalam Rumah Tangga; 2. hakim belum mengetahui lembaga mana yang ditunjuk untuk memberikan layanan konseling bagi pelaku kekerasan di Pengadilan Negeri Yogyakarta dan Pengadilan Negeri Bantul, karena menurut penjelasan dari Pasal 50 huruf b Undang-Undang Nomor 23 Tahun 2004 tentang Penghapusan Kekerasan Dalam Rumah Tangga, tertulis lembaga tersebut sudah terakreditasi menyediakan konseling layanan bagi pelaku,misalnya rumah sakit, klinik, kelompok konselor, atau yang mempunyai keahlian memberikan konseling bagi pelaku KDRT. 3. masalah pembiayaannya belum jelas akan dibebankan kepada siapa. 4. rujukan Pedoman program konseling yang akan diterapkan belum ada. 5. belum jelas mana saja lembaga yang ditunjuk atau yang bekerjasama sebagai pelaksana program konseling. 6. belum pernah dilakukan sosialisasi ke Pengadilan-pengadilan atau pun aparat penegak hukum.

\section{Kebijakan Kebijakan Aplikatif yang Efektif Kedepan dalam Penerapan Pidana Tambahan Konseling}

Kaitannya dengan sanksi pidana tindakan berupa penerapan sanksi pidana tambahan berupa mengikuti program konseling bagi pelaku KDRT merupakan suatu kebijakan aplikatif yang efektif kedepan dalam penerapan pidana 
tambahan konseling namun, perlu ada perbaikan maupun revisi aturan yang ada yakni UU PKDRT agar lebih memperjelas aturan aplikatif pidana tambahan berupa konseling kedepan.

Berdasarkan data wawancara pada implementasi konseling pada tindak pidana KDRT menurut hakim Pengadilan Negeri Yogyakarta, Undang-Undang sebaiknya harus berdasarkan prinsip-prinsip yang jelas, aparat penegak hukumnya sebaiknya harus tegas menjalankan. Budaya masyarakat dengan melakukan pendekatan serta melakukan penyuluhan, seharusnya mengadopsi Undang-Undang Peradilan Anak, melakukan penelitian kemasyarakatan, latar belakang melakukan kejahatan informasi lingkungan keluarga tetangga masyarakat tempat kerja agar bisa bekerja sama agar informasi yang didapat lebih akurat, tugas permasyarakat lebih akurat lagi..21

Masukan untuk implementasi konseling pada tindak pidana KDRT kedepan menurut hakim Pengadilan Negeri Bantul, jika memang konseling memang diutamakan, seharusnya konseling secara jelas dianggarkan langsung dan proses konseling seharusnya dilakukan sejak awal, dimulai dari penyidikan penuntutan sehingga ketika masuk ke Pengadilan hakim bisa memberikan putusan yang adil. Hakim menjadikan itu sebagai pertimbangan dan juga LSM dan lembaga-lembaga terkait menyusun serta menyampaikan program yang bersangkutan (kaitannya dengan konseling) yang jelas serta melakukan penyuluhan dan pemerintah mengeluarkan peraturan pemerintah untuk pelaksanaan sehingga ada kader yang dibentuk dan ditunjuk sehingga penegak hukum dalam menerapkan konseling tidak kebingungan. ${ }^{22}$

Jika melihat pandangan korban maupun perkara KDRT yang memang dikehendaki melalui sanksi tindakan ini merupakan alternatif yang patut dipilih oleh korban dan pelaku. Banyaknya perempuan yang menginginkan pasangan hidupnya merubah perilaku mereka tetapi tidak menginginkan berpisah dengan pasangannya.

Melihat seberapa jauh kebijakan aplikatif yang efektif kedepan dalam penerapan pidana tambahan konseling sebaiknya diperhatikan beberapa hal:

${ }^{21}$ Wawancara dengan hakim PN Sleman.

${ }^{22}$ Wawancaradengan hakim PN Bantul. 
Pertama, diperlukan aturan yang lebih jelas di dalam mengatur aturan pidana konseling jika diterapkan, Pada dasarnya aturan konseling ini menginformasikan langkah-langkah untuk melakukan konseling bagi pelaku KDRT, sebagai bagian dari tahapan intervensi. Langkah tahapan pada aturan konseling bagi pelaku KDRT ini didasarkan oleh pelajaran (lesson learned) pada konseling korban KDRT, bahwa pelaku KDRT pun juga tidak luput dari kebutuhan untuk membagi informasi mengenai perasaan yang pernah menghinggapi pelaku saat melakukan kekerasan. Dengan demikian, aturan konseling ini ingin menjadi materi yang tepat untuk para konselor agar dapat memotivasi pelaku KDRT untuk tidak lagi melakukan kekerasan dikemudian hari. Berdasarkan hal tersebut, materi dalam aturan konseling ini terdiri dari assessment, konseling, edukasi dan terapi. Kesemuanya merupakan tahapan intervensi bagi pelaku KDRT. ${ }^{23}$ Secara umum, tujuannya adalah mendorong pelaku mengambil tanggung jawab untuk menghentikan tindak kekerasan dan meningkatkan kualitasnya hidupnya sendiri. Dengan demikian, hal-hal penting dalam program diharapkan dapat mendorong pelaku agar: a) menyadari bahwa tindakannya melanggar hukum; b) dapat berempati dan sungguh-sungguh menyesali perbuatannya; c) dapat mengendalikan diri dari kekerasan termasuk reintegrasi kembali ke lingkungan keluarga.

Kedua, Harus ada pembentukan tim penanganan yang terdiri dari unsur dinas/instansi/unit kerja yang terkait serta organisasi dan LSM yang peduli perbaikan korban dan pelaku dari tindak kekerasan. Penentuan komposisi tim yang terdiri dari tim pengarah, tim teknis dan kelompok kerja bidang pencegahan, penanganan dan pemulihan, serta bidang pendidikan dan advokasi.

Ketiga, bahwa pedoman pemidanaan konseling kedepan seyogyanya disusun oleh Mahkamah Agung, karena panduan tersebut masih termasuk dalam lingkup tugas peradilan dan secara yuridis formal, kekuasaan kehakiman di Indonesia dijamin kemandiriannya. Jika panduan tersebut disusun oleh lembaga khusus yang diberi wewenang oleh parlemen (DPR) maka produk yang kemungkinan akan banyak terkontaminasi unsur-unsur politis yang

${ }^{23}$ Core Group, Modul Konseling Bagi Pelaku Kekerasan Dalam Rumah Tangga (KDRT), Mitra Perempuan, Jakarta, 2008, hlm.7. 
mendominasi perbuatan pedoman tersebut, dan secara yuridis DPR Indonesia hanya mempunyai fungsi legislasi (legislation), anggaran (Budget), dan Pengawasan (control). Padahal, panduan pemidanaan tersebut bukan merupakan pedoman bagi Hakim yang akan menjatuhkan pidana terhadap pelaku KDRT sehingga bersifat regulasi (regulation). ${ }^{24}$

Keempat, untuk masalah anggaran maka pelaksanaan konseling akan dibebankan kepada siapa, bisa mengadopsi pada UU Peradilan Anak No. 23 Tahun 2002 pada Pasal 59 dijelaskan pemerintah dan lembaga negara lainya berkewajiban dan bertanggung jawab untuk memberikan perlindungan khusus kepada anak yang berhadapan dengan hukum, perlindungan khusus yang dimaksud terdapat pada Pasal 64 ayat (2) point B penyedia petugas pendamping khusus, sama halnya dengan tindak pidana KDRT penerapan pidana tambahan konseling ini diharapkan menjadi tanggung jawab negara karena melihat tujuannya untuk menekan angka kenaikan tindak pidana KDRT agar pelaku tidak mengulangi KDRT kembali.

Untuk lembaga-lembaga yang bisa diminta bekerja sama saat ini di Indonesia sudah banyak LSM yang fokus di bidang pemerhati terhadap tindak kekerasan seperti Dalam memberikan konseling bagi pelaku kekerasan, Rifka Annisa, Mitra Perempuan, Resko Dyah Utami Yogyakarta, The Gender Based Violence Partnership(GBV),Mosaic, Training, Service and Healing Centre for Women, RutgersWorld Population Foundation serta masih banyak lagi LSM yang bisa diajak bekerja sama dalam mewujudkan alternatif penerapan konseling bagi pelaku KDRT agar tidak mengulangi tindak kekerasannya lagi.

Kelima, salah satu alternatif langkah konseling yang bisa digunakan dalam menjalankan program konseling, Langkahnya sebagai berikut:25 1 . sesi assesment, perkenalan dan membangun relasi; 2. sesi assesment dengan kuesioner; 3 . sesi kesetaraan perempuan dan laki-laki; 4. sesi tindak kekerasan dalam rumah tangga; 5. sesi membangun motivasi perubahan perilaku diri; 6 . sesi mengelola pikiran dan emosi negatif; 7. sesi mengelola konflik; 8. sesi mengelola amarah; 9. sesi teknik relaksasi; 10. sesi ritual melepas pola perilaku kekerasan.

\footnotetext{
${ }^{24}$ http://www.komnasperempuan.or.id/wp-content/uploads/2013/12/CATAHU, $\quad$ diakses 22 September 2015.

${ }^{25}$ Core Group, Op.Cit, hlm,12-49.
} 


\section{Penutup}

Di Indonesia di dalam UU PKDRT selain sanksi pidana penjara juga terdapat sanksi alternatif berupa denda atau pidana tambahan. Pada implementasinya di Pengadilan Negeri Yogyakarta dan Pengadilan Negeri Bantul (2010-2014) ditemukan sanksi pidana yang diputuskan seluruhnyaberupa pidana penjara.Sejauh temuan dalam penelitian ini, belum ada perkara KDRT yang dijatuhi pidana alternatif denda.Kecenderungan hakim ini disebabkan beberapa faktor diantaranya : 1 . pidana penjara masih dianggap dapat digunakan sebagai sarana yang memadai untuk menanggulangi tindak pidana KDRT, 2. belum tersedianya jenis sanksi pidana alternatif lain selain pidana penjara yang lebih efektif jika pidana selain itu diterapkan. 3. jaksa cukup menuntut dengan pidana penjara saja, 4. di pengadilan penerapan sanksi tindakan berupa mengikuti program mengikuti program konseling belum bisa diterapkan karena banyaknya syarat yang harus dipenuhi dan belum ada standar operasional prosedurnya.

Kebijakan aplikatif yang efektif kedepan dalam penerapan pidana tambahan konseling akan efektif jika diterapkan double track system. Adanya kesetaraan kedudukan sanksi pidana dan sanksi tindakan sangat bermanfaat untuk memaksimalkan kedua jenis sanksi tersebut secara tepat dan proporsional, sebab kebijakan sanksi yang integral dan seimbang (sanksi pidana dan tindakan). Masih terdapat kendala dalam penerapan pidana tambahan berupa konseling hal itu dikarenakan ada beberapa kendala yakni : 1 . belum pernah ada tuntutan/dakwaan dari Jaksa yang menggunakan Pasal 50 huruf b UndangUndang Nomor 23 Tahun 2004 tentang Penghapusan Kekerasan Dalam Rumah Tangga; 2. hakim belum mengetahui lembaga mana yang ditunjuk untuk memberikan layanan konseling bagi pelaku kekerasan di Pengadilan Negeri Yogyakarta dan Pengadilan Negeri Bantul, 3. masalah pembiayaannya belum jelas akan dibebankan kepada siapa.4. rujukan pedoman program konseling yang akan diterapkan belum ada.5. belum jelas mana saja lembaga yang ditunjuk atau yang bekerjasama sebagai pelaksana program konseling. 6. belum pernah dilakukan sosialisasi ke Pengadilan-pengadilan atau pun aparat penegak hukum. 
Sebagai alternatifnya, konseling dapat diterapkan misalnya melalui langkah konseling sebagai berikut: 1 . sesi assesmen, Perkenalan dan membangun relasi, 2. sesi assesmen dengan kuesioner, 3. sesi kesetaraan perempuan dan lakilaki, 4. sesi tindak kekerasan dalam rumah tangga, 5. sesi membangun motivasi perubahan perilaku diri, 6. sesi mengelola pikiran dan emosi negatif, 7. sesi mengelola konflik, 8. sesi sesi teknik relaksasi 9. mengelola amarah, 10. sesi ritual melepas pola perilaku kekerasan.

\section{Daftar Pustaka}

Andreea, Vesa, "International and Regional Standards for Protecting Victims of Domestic Violence" American University Journal of Gender, Social Policy and the Law, 2004.

Anthony dan Berryman's. The Process of Sentencing, Butterworths, London, 2000.

Core Group, Modul KonselingBagiPelakuKekerasanDalamRumahTangga (KDRT), Mitra Perempuan, Jakarta, 2008.

Elmina Martha, Aroma, Proses Pembentukan Hukum Kekerasan Terhadap Perempuan di Indonesia dan Malaysia, Aswaja, Yogyakarta, 2013.

, Perempuan dan Kekerasan Rumah Tangga di Indonesia dan Malaysia, FH UII Press, Yogyakarta, 2012.

Hadiati Soersosno, Moerti, Kekerasan dalam Rumah Tangga dalam PersepektifYuridisViktimologis, Sinar Grafika, Jakarta, 2010.

Hamzah, Andi, Sistem Pidana dan Pemidanaan Indonesia, Dari Retribusi ke Reformasi. PT Pradnya Paramita, Jakarta, 1986.

Hardiati Koeswadji, Hermien, Perkembangan Macam-Macam Pidana dalam Rangka Perkembangan Hukum Pidana, PT. Citra Aditya Bakti, Bandung,1995.

Lamintang, P.A.F., dan Theo Lamintang, Hukum Penitensier Indonesia, Sinar Grafika, Jakarta, 2012.

Moeljatno, Asas-Asas Hukum Pidana, Bina Aksara, Jakarta, 1987.

Nurhayati, Elly, Panduan Untuk Perempuan Korban Kekerasan, Pustaka Pelajar, Yogyakarta, 2000.

Praudi, Guse, Berbagai Aspek Tindak Pidana Kekerasan dalam Rumah Tangga, Merkid Press, Yogyakarta, 2012.

Syaiful Bakhri, Perkembangan Stelsel Pidana Indonesia, Total Media, Yogyakarta, 2009. 
Undang-Undang Nomor 23 Tahun 2004 Tentag Penghapusan Kekerasan Dalam Rumah Tangga

Wawancara dengan Asep Permana, S.H., M.,H. Hakim Pengadilan Negeri Yogyakarta, tanggal 29 Juni 2015, di Ruang Hakim Pengadilan Negeri Yogyakarta.

Wawancara dengan Bayu Soho Rahardjo, S.H., Hakim Pengadilan Negeri Bantul, tanggal 5 Agustus 2015, di Ruang Mediasi Pengadilan Negeri Bantul.

http:// print.kompas.com/baca/2015/04/27/Laporan-KDRT-Meningkat\%2cPenanganan-Belum-Optimal.

http://www.komnasperempuan.or.id/wp-content/uploads/2013/12/CATAHU. 